\title{
PENERAPAN PROJECT WORK PADA MATA KULIAH KAIWA MAHASISWA BAHASA JEPANG FKIP UNRI
}

\author{
Dini Budiani dan Merri Silvia Basri \\ Program Studi Pendidikan Bahasa Jepang FKIP Universitas Riau \\ Email: Dini.budiani@lecturer.unri.ac.id
}

\begin{abstract}
ABSTRAK. Penelitian ini bertujuan untuk meningkatkan kemampuan berkomunikasi, dalam pembelajaran percakapan (kaiwa) pada mahasiswa pendidikan bahasa Jepang FKIP UNRI. Banyak latihan-latihan percakapan hanya terfokus pada latihan pola kalimat dan menghafal contoh percakapan yang terdapat dalam buku teks. Pola pembelajaran seperti itu menyebabkan pembelajar tidak mampu mengungkapkan apa yang mereka ingin sampaikan dalam lingkup nyata komunikasi bahasa Jepang. Penelitian ini mencoba untuk mengatasi hal tersebut dengan menerapkan project work dalam perkuliahan percakapan. Tujuan penelitian ini adalah untuk melihat keterlibatan pembelajar dalam perkuliahan kaiwa menggunakan project work dan mencari tahu pendapat mereka tentang metode tersebut. Data penelitian ini adalah 44 orang pembelajar Prodi Pendidikan Bahasa Jepang FKIP UNRI yang mengambil mata kuliah Kaiwa 4. Dari hasil penelitian terlihat bahwa selama penerapan project work pembelajar terlibat secara aktif dalam pembelajaran walaupun seluruh percakapan berlangsung dalam bahasa Jepang. Pembelajar yang dalam perkuliahan biasa cenderung pasif pun berusaha untuk mengutarakan pendapatnya walaupun mereka mengalami hambatan kebahasaan saat berkomunikasi. Dari hasil angket yang menanyakan mengenai pendapat pembelajar, ditemukan bahwa hampir seluruh pembelajar memiliki kesan yang positif terhadap penerapan project work pada mata kuliah Kaiwa 4.
\end{abstract}

Keywords : Pembelajaran bahasa Jepang, pembelajaran kaiwa, project work, kemampuan berkomunikasi

ABSTRACT. This study aims to improve communication skills, in learning conversation (kaiwa) in Japanese language student of teacher training and education faculty Riau University. Many conversation exercises are only focused on practising sentence pattern and memorizing of conversation examples contained in the textbook. Thus learning pattern causes learners not to be able to express what they want to convey in the real scope of communication in Japanese language. This study tries to overcome the problem by implementing project work in conversation lectures. The purpose of this study is to see the involvement of learners in the lectures using project work and find out their opinions about the method. The data of this study were 44 students of Japanese Language Education Study Program of Teacher Training and Education Faculty Riau University. From the result of the study, it was seen that during the project work implementation the learners were actively involved in learning even though they experience language barrier when communicating. From the result of the questionnaire that asked about learners' opinion, it was found that almost all learners had a positive impression of the project work on the Kaiwa 4 subject.

Keywords: Japanese language learning, kaiwa learning, project work, communication skillsS 


\section{PENDAHULUAN}

Berdasarkan hasil survei the Japan Foundation tahun 2012, pembelajar bahasa Jepang di Indonesia menduduki posisi nomor dua terbanyak di dunia setelah China, dengan pembelajar sebanyak lebih dari 870.000 orang dengan jumlah pengajar bahasa Jepang sekitar 4.500 orang (survei The Japan Foundation, 2013). Dibandingkan dengan hasil survei tahun 2009, jumlah pembelajar dan pengajar bahasa Jepang pada tahun 2012 mengalami peningkatan. Hal ini menunjukkan semakin tingginya ketertarikan orang Indonesia untuk mempelajari bahasa Jepang dari tahun ke tahun. Hal ini dapat didorong karena ketertarikan akan budaya kontemporer Jepang, dan maraknya kesempatan bekerja dan melanjutkan pendidikan di Jepang.

Saat seseorang mempelajari bahasa asing, tidak terkecuali bahasa Jepang, sering kali pembelajaran mengenai tata bahasa dan kosakata dianggap sebagai faktor terpenting penunjang pemerolehan bahasa. Namun pada kenyataannya, selain kedua hal tersebut, terdapat empat aspek keterampilan berbahasa yang harus dikuasai oleh pembelajar agar dapat berkomunikasi dalam bahasa asing tersebut. Keempat aspek keterampilan berbahasa tersebut mencakup keterampilan menyimak (聴解能力), keterampilan membaca (読解能力), keterampilan berbicara (会話能力), dan keterampilan menulis (作文能力).

Dalam penyelenggaraan pendidikan bahasa Jepang di Indonesia pun keempat aspek keterampilan berbahasa ini dimasukkan ke dalam kurikulum pembelajaran untuk menunjang kemampuan komunikasi pembelajar. Dari keempat aspek keterampilan berbahasa tersebut, keterampilan berbicara sangat sulit diasah saat pendidikan bahasa
Jepang dilaksanakan di luar Jepang. Ini salah satunya dikarenakan keterbatasan jumlah native speaker bahasa Jepang sebagai partner berbicara bagi pembelajar. Tidak jarang ditemui pembelajar bahasa Jepang orang Indonesia yang tidak pernah berkomunikasi langsung dengan native speaker bahasa Jepang. Banyak pembelajar bahasa Jepang yang hanya berkomunikasi dalam bahasa Jepang dengan pengajar atau teman sejawat. Dan komunikasi yang dilakukan tersebut hanya terbatas pada kepentingan pengajaran dan bukan kepentingan berkomunikasi.

Selain itu, pelaksanaan pembelajaran berbicara (selanjutnya disebut pembelajaran kaiwa) yang monoton, sehingga mengurangi motivasi pembelajar untuk berbicara dalam bahasa Jepang juga merupakan salah satu faktor penyebab rendahnya kemampuan berbicara pembelajar.

Apabila melihat pelaksanaan pembelajaran kaiwa tingkat dasar di Universitas Riau, selama ini pengajar banyak memfokuskan pada penghafalan bentuk-bentuk percakapan saja. Walaupun proses menghafal percakapan sangat penting untuk memberikan input pelafalan bahasa Jepang yang benar, namun apabila dilaksanakan secara terus menerus akan dapat mengurangi motivasi pembelajar untuk berkomunikasi secara mandiri karena pembelajar tidak diasah untuk berfikir dan mengutarakan idenya saat berbicara.

Selain menghafal bentuk-bentuk percakapan, pengajar bahasa Jepang sering kali hanya mementingkan ketercapaian penggunaan pola kalimat dan kosa kata yang telah dipelajari sebelumnya, tanpa melihat kepentingan berkomunikasi. Misalnya, pada sebuah kelas yang telah menuntaskan pelajaran tata bahasa bentuk sopan dalam bahasa Jepang, pengajar sering kali menerapkan roleplay sebagai bentuk latihan berbicara. Roleplay 
tersebut dirancang dengan menetapkan situasi dimana bentuk sopan bahasa Jepang biasa digunakan. Persepsi pengajar akan pentingnya tata bahasa dan kosakata pada saat berbicara ini ternyata berpengaruh terhadap pembelajar, sehingga muncul kecemasan pembelajar bahwa dirinya akan melakukan kesalahan tata bahasa dan kosa kata saat berbicara. Hal inilah yang menyebabkan pembelajar takut untuk berkomunikasi dan cenderung menarik diri dari pembelajaran kaiwa.

Melihat kondisi tersebut, sebagai pengampu mata kuliah kaiwa dasar pada pembelajar tahun ajaran 2014/2015, penulis berupaya untuk mencari solusi pengajaran kaiwa yang lebih menghargai proses berfikir dan mempertimbangkan kepentingan komunikasi. Dengan harapan pembelajar dapat lebih aktif berpartisipasi dalam mata kuliah kaiwa. Salah satu solusi pengajaran tersebut adalah dengan penerapan project work pada mata kuliah kaiwa dasar.

Menurut Kono (2003) penerapan project work pada pembelajaran kaiwa dapat meningkatkan keterlibatan pembelajar dalam pembelajaran kaiwa. Selain itu, penerapan project work pada pembelajaran kaiwa dapat meningkatkan intensitas berbicara dalam bahasa Jepang.

Penelitian ini bertujuan untuk melihat keterlibatan pembelajar di dalam kelas saat penerapan project work pada mata kuliah kaiwa dasar dan penerapan penerapan project work pada mata kuliah kaiwa.

\section{Kajian Teoritis}

Dalam Kamus Besar Bahasa Indonesia (versi online) disebutkan bahwa berbicara adalah "berkata, bercakap, berbahasa atau melahirkan pendapat (dengan perkataan, tulisan, dan sebagainya) atau berunding".
Sementara itu, menurut Tarigan (2008:16) berbicara adalah kemampuan mengucapkan bunyi-bunyi artikulasi atau kata-kata untuk mengekspresikan, menyatakan serta menyampaikan pikiran, gagasan, dan perasaan. Sedangkan sebagai bentuk atau wujudnya berbicara disebut sebagai suatu alat untuk mengkomunikasikan gagasan-gagasan serta dikembangkan sesuai dengan ke-butuhankebutuhan sang pendengar atau penyimak. Dari kedua pengertian mengenai berbicara di atas, dapat disimpulkan bahwa saat seseorang berbicara, maka terdapat tujuan yang ingin dicapai melalui kata-kata yang diucapkan.

Sejalan dengan kedua pengertian tersebut, The Japan Foundation (2007: 3) menjelaskan bahwa saat seseorang berbicara, ada 3 proses yang dilalui. (a) Seseorang harus memikirkan isi yang ingin dibicarakan, (b) Seseorang harus memikirkan bagaimana mengungkapkan isi yang ingin dibicarakan, (c) berbicara. Proses ini menunjukkan bahwa sebelum seseorang benar-benar berbicara kepada lawan bicara, dia terlebih dahulu harus memikirkan isi dari pesan dan kata-kata yang digunakan untuk mengungkapkan pesan tersebut.

Saat pembicara dan lawan berbicara berkomunikasi, aim, information gap, choice of response dan response adalah 4 syarat terlaksananya komunikasi (The Japan Foundation, 2007:11). Aim berarti bahwa setiap komunikasi memiliki tujuan, baik itu berupa pengungkapan perasaan, pendapat, idea tau hanya berupa percakapan basa basi dalam rangka menjaga hubungan baik antara pembicara dan lawan bicara. Seementara information gap berarti, saat berkomunikasi diperlukan perbedaan informasi antara pembicara dan lawan bicara. Perbedaan informasi inilah yang mendorong orang untuk melakukan komunikasi. Pada saat ber- 
komunikasi juga yang tak kalah pentingnya adalah pilihan untuk mengungkapkan pesan (choice of response). Yang dimaksud dengan pilihan di sini adalah seseorang dapat memilih penggunaan kosa kata, ungkapan dan kalimat yang digunakan saat berkomunikasi. Dan terakhir, saat berkomunikasi, lazimnya pembicara dan lawan bicara akan menunjukkan respon terhadap apa yang dibicarakan. Respon dari lawan bicara akan sangat mempengaruhi keberlangsungan komunikasi.

\section{Pembelajaran Kaiwa}

Canal dalam The Japan Foundation (2007) menyebutkan bahwa saat seseorang berkomunikasi, ada 4 kompetensi komunikasi yang harus dimiliki, yaitu (a) kompetensi tata bahasa, (b) kompetensi sosiolinguistik (c) kompetensi wacana, dan (d) kompetensi strategi.

Yang dimaksud dengan kompetensi tata bahasa adalah kemampuan untuk menggunakan tata bahasa, kosa kata, tulisan, sistem bunyi sebuah bahasa. Sedangkan kompetensi sosiolinguistik adalah kemampuan seseorang untuk dapat menggunakan bahasa yang memper-timbangkan lawan bicara, situasi, kondisi dan waktu saat terjadinya komunikasi.

Kemudian yang dimaksud dengan kompetensi wacana adalah kemampuan seseorang untuk dapat menggunakan tuturan berupa wacana, bukan hanya berupa kata per kata atau kalimat per kalimat saja. Saat seseorang disebut mampu berkomunikasi, kalimat- kalimat tutur yang digunakannya harus memiliki hubungan (koherensi) dan saling terikat (kohesi).

Terakhir, yang dimaksud dengan kompetensi strategi adalah kemampuan seseorang untuk mengatasi hambatan-hambatan komunikasi yang terjadi. Misalnya, pada saat lawan bicara tidak mampu memahami apa yang disampaikan, pembicara mengulang kembali perkataan sambil meng-gunakan gestur agar lawan bicara dapat menangkap pesan yang ingin disampaikan.

Pada pembelajaran kaiwa, dimana mendidik pembelajar untuk mampu berbicara adalah tujuan dari pembelajaran itu sendiri, 4 kompetensi komunikasi ini hendaknya diaplikasikan secara keseluruhan.

Menurut Sutedi (2009), Proses pembelajaran yang berhubungan dengan kegiatan belajar mengajar (KBM) ditentukan oleh beberapa faktor utama, yaitu (a) kemampuan guru dalam mengajar, (b) kondisi siswa saat KBM berlangsung, (c) bahan ajar, dan (d) penggunaan metode dan media ajar.

Pendapat Sutedi ini menunjukkan bahwa penggunaan metode dan media ajar merupakan suatu faktor yang mempengaruhi tercapainya tujuan KBM. Begitu juga dengan pembelajaran Kaiwa. Pengajar hendaknya mampu menggunakan metode pembelajaran yang melibatkan 4 kompetensi komunikasi yang telah disebutkan sebelumnya.

Menurut The Japan Foundation (2007), ada beberapa metode latihan berbicara yang mengimplementasikan 4 kompetensi komunikasi. Diantaranya adalah; interviu, pidato, diskusi dan roleplay.

a) Interviu

Interviu adalah kegiatan komunikasi untuk mendapatkan informasi yang diinginkan dengan melakukan tanya jawab. Pertanyaan yang diajukan meliputi $5 \mathrm{~W} 1 \mathrm{H}$; what, where, when, who, why, how. Informasi yang didapat melalui interviu selanjutnya akan dapat di-jadikan data untuk menyusun laporan, penelitian. 
b) Pidato

Pidato adalah kegiatan menyampaikan ide, perasaan, tanggapan mengenai suatu hal dengan berbicara di depan khalayak ramai. Penerapan pidato pada pembelajaran kaiwa dapat melatih kemam-puan pembelajar untuk menyusun waca-na yang saling berkohesi dan berko-herensi.

c) Diskusi

Diskusi adalah kegiatan yang dilakukan oleh beberapa orang yang saling bertukar pendapat, ide dan perasaan untuk menyelesaikan suatu masalah.

d) Roleplay

Roleplay adalah kegiatan dimana pembelajar diberikan suatu situasi tertentu dengan suatu peran yang telah ditentukan untuk mencapai tujuan kebahasaan tertentu. Pada pembelajaran kaiwa, penerapan roleplay terutama dapat melatih kompetensi sosiolinguistik dan kompetensi wacana pembelajar.

\section{Project Work}

Salah satu Negara yang aktif menerapkan project work dalam pembelajaran adalah Singapura. Menurut Kementerian Pendidikan Singapura dalam laman websitenya,

"Project Work is a learning experience which aims to provide students with the opportunity to synthesise knowledge from various areas of learning, and critically and creatively apply it to real life."

"Project work adalah sebuah pengalaman belajar yang bertujuan untuk memberikan kesempatan bagi pelajar untuk memperoleh pengetahuan dari beberapa bidang ilmu, dan secara kritis dan kreatif mengaplikasikannya dalam kehidupan nyata."

Project work adalah kegiatan belajar yang dilakukan oleh sekelompok orang yang memiliki tujuan tertentu, dan demi mencapai tujuan tersebut mereka saling berkomunikasi, berdiskusi, dan mencari informasi.

Terdapat 4 faktor penting dalam project work, yaitu (a) knowledge ap-plication, (b) communication, (c) colla-boration, (d) independent learning.

Menurut Katanihoka dalam Kono (2003), project work dapat meningkatkan kerjasama tim melalui keterlibatan masingmasing anggota tim, pembagian tugas yang merata dan penyamaan persepsi.

\section{METODE PENELITIAN}

Penelitian ini adalah penelitian tindakan kelas yang bermaksud untuk mencari solusi bagi pelaksanaan pembelajaran di kelas.

Menurut Sanjaya (2010:25), Secara bahasa ada tiga istilah yang berkaitan dengan penelitian tindakan keleas (PTK), yakni penelitian, tindakan, dan kelas. Pertama, penelitian adalah suatu perlakuan yang menggunakan metodologi untuk memecahkan suatu masalah. Kedua, tindakan dapat diartikan sebagai perlakuan yang dilakukan oleh guru untuk memperbaiki mutu. Ketiga kelas menunjukkan pada tempat berlangsungnya tindakan.

Pada penelitian ini, penulis akan menerapkan project work di mata kuliah kaiwa dasar sebanyak empat kali pertemuan. Adapun garis besar rencana pelaksanaan pembelajaran (RPP) 4 pertemuan tersebut dapat dilihat pada tabel 1 .

Objek penelitian adalah mahasiswa tahun ajaran 2014/2015 yang mengambil mata kuliah kaiwa 4 ( kaiwa dasar) sebanyak 44 orang. Mahasiswa tersebut telah menyelesaikan pembelajaran bahasa Jepang di Universitas Riau selama kurang lebih 1200 jam, atau setara dengan pembelajar bahasa 
Jepang tingkat dasar. Apabila dilihat dari hasil Ujian Kemampuan Bahasa Jepang (UKBJ) yang diselenggarakan oleh Pemerintah Jepang di bawah The Japan Foundation, kemampuan sebagian besar pembelajar angkatan 2014/2015 adalah setingkat UKBJ level N5.

Pada penelitian ini, data penelitian berupa observasi pengajar terhadap pelaksanaan mata kuliah kaiwa. Selain itu, diambil juga data berupa hasil lembar kerja dan pendapat pembelajar mengenai penerapan project work.

Pada penelitian ini digunakan 3 macam instrument penelitian.

a) Rencana Pelaksanaan Pembelajaran Berikut adalah tabel rencana pelaksanaan pembelajaran mata kuliah kaiwa dasar dengan penerapan project work.

b) Lembar Kerja

Untuk melihat partisipasi pembelajar, penulis menyiapkan lembar kerja yang harus diisi oleh masing-masing pembelajar. Lembar kerja tersebut berisi pertanyaan-pertanyaan yang ditanyakan oleh pembelajar kepada teman sejawat dan berisi jawaban-jawaban dari teman sejawat atas pertanyaan yang diajukan.

c) Angket

Dalam penelitian ini, penulis menggunakan 2 macam angket. Angket tertutup dan angket terbuka. Angket terbuka bertujuan sebagai evaluasi diri sendiri bagi pembelajar mengenai pembelajaran kaiwa dengan penerapan project work. Sementara, angket tertutup bertujuan untuk melihat tanggapan pembelajar terhadap pembelajaran kaiwa dan penerapan project work.
Tabel. 2 Rencana Pelaksanaan Pembelajaran Mata Kuliah Kaiwa

\begin{tabular}{|c|c|c|c|}
\hline $\begin{array}{c}\text { Pertemua } \\
\mathrm{n}\end{array}$ & Kegiatan & Uraian & $\begin{array}{c}\text { Wakt } \\
\mathrm{u}\end{array}$ \\
\hline \multirow[t]{6}{*}{1} & $\begin{array}{l}\text { Kegiatan } \\
\text { awal }\end{array}$ & $\begin{array}{lc}\bullet & \text { Salam } \\
\text { dan pembukaan } \\
\text { - } & \text { Penjelasa } \\
\mathrm{n} & \text { mengenai } \\
\text { project } & \text { work }\end{array}$ & $\begin{array}{l}15 \\
\text { menit }\end{array}$ \\
\hline & $\begin{array}{l}\text { Persiapa } \\
n\end{array}$ & $\begin{array}{l}\text { - Pembagi } \\
\text { an kelompok } \\
\text { - } \quad \text { Perkenal } \\
\text { an tema }\end{array}$ & $\begin{array}{l}15 \\
\text { menit }\end{array}$ \\
\hline & \multirow[t]{3}{*}{$\begin{array}{l}\text { Kegiatan } \\
\text { Inti }\end{array}$} & $\begin{array}{l}\text { - } \\
\text { ar } \quad \text { Pembelaj } \\
\text { memilih terdiskusi } \\
\text { yang menarik }\end{array}$ & $\begin{array}{l}15 \\
\text { menit }\end{array}$ \\
\hline & & $\begin{array}{l}\text { - Masing- } \\
\text { masing } \\
\text { pembelajar } \\
\text { memikirkan } 4 \\
\text { buah pertanyaan } \\
\text { yang ingin mereka } \\
\text { tanyakan ke teman } \\
\text { sejawat }\end{array}$ & $\begin{array}{l}20 \\
\text { menit }\end{array}$ \\
\hline & & $\begin{array}{l}\text { - Pembelaj } \\
\text { ar berdiskusi } \\
\text { menentukan } \\
\text { pertanyaan yang } \\
\text { ingin ditanyakan } \\
\text { ke teman sejawat }\end{array}$ & $\begin{array}{l}30 \\
\text { menit }\end{array}$ \\
\hline & Penutup & $\begin{array}{l}\text { - Pengajar } \\
\text { menjelaskan } \\
\text { bahwa pertanyaan } \\
\text { yang sudah } \\
\text { disusun akan } \\
\text { dijadikan } \\
\text { pertanyaan } \\
\text { interviu yang } \\
\text { diadakan pada } \\
\text { pertemuan } \\
\text { berikutnya. }\end{array}$ & $\begin{array}{l}5 \\
\text { menit }\end{array}$ \\
\hline 2 & $\begin{array}{l}\text { Kegiatan } \\
\text { awal }\end{array}$ & $\begin{array}{l}\text { - Salam } \\
\text { dan pembukaan } \\
\text { - } \quad \text { Penjelasa } \\
\text { n mengenai } \\
\text { pelaksanaan }\end{array}$ & $\begin{array}{l}20 \\
\text { menit }\end{array}$ \\
\hline
\end{tabular}




\begin{tabular}{|c|c|c|c|}
\hline & & $\begin{array}{l}\text { interviu } \\
\text { - Pengajar } \\
\text { membagikan } \\
\text { lembar kerja }\end{array}$ & \\
\hline & $\begin{array}{l}\text { Kegiatan } \\
\text { inti }\end{array}$ & $\begin{array}{l}\text { - Masing- } \\
\text { masing } \\
\text { pembelajar } \\
\text { membagi tugas } \\
\text { interviu } \\
\text { - Masing- } \\
\text { masing } \\
\text { pembelajar } \\
\text { melaksanakan } \\
\text { interviu sesuai } \\
\text { dengan pembagian } \\
\text { tugas yang telah } \\
\text { ditentukan } \\
\text { sebelumnya }\end{array}$ & $\begin{array}{l}65 \\
\text { menit }\end{array}$ \\
\hline & Penutup & $\begin{array}{l}\text { - Pengajar } \\
\text { menanyakan } \\
\text { kesan setelah } \\
\text { dilaksanakannya } \\
\text { interviu } \\
\text { - Pengajar } \\
\text { menjelaskan } \\
\text { tentang presentasi } \\
\text { hasil interviu yang } \\
\text { akan diadakan di } 2 \\
\text { pertemuan } \\
\text { berikutnya }\end{array}$ & $\begin{array}{l}15 \\
\text { menit }\end{array}$ \\
\hline 3 & $\begin{array}{l}\text { Kegiatan } \\
\text { awal }\end{array}$ & $\begin{array}{lc}\bullet & \text { Salam } \\
\text { dan pembukaan } \\
\text { - } \quad \text { Pengajar } \\
\text { penjelaskan tata } \\
\text { cara presentasi }\end{array}$ & $\begin{array}{l}20 \\
\text { menit }\end{array}$ \\
\hline & $\begin{array}{l}\text { Kegiatan } \\
\text { inti }\end{array}$ & $\begin{array}{ll} & \text { Presentas } \\
\text { i } 7 \text { grup }\end{array}$ & $\begin{array}{l}70 \\
\text { menit }\end{array}$ \\
\hline & $\begin{array}{l}\text { Kegiatan } \\
\text { penutup }\end{array}$ & $\begin{array}{l}\text { - Pengajar } \\
\text { memberikan } \\
\text { tanggapan } \\
\text { terhadap } \\
\text { presentasi } \\
\text { pembelajar }\end{array}$ & $\begin{array}{l}10 \\
\text { menit }\end{array}$ \\
\hline 4 & $\begin{array}{l}\text { Kegiatan } \\
\text { awal }\end{array}$ & $\begin{array}{lc}\bullet & \text { Salam } \\
\text { dan pembukaan } \\
\text { - } \quad \text { Pengajar } \\
\text { penjelaskan tata } \\
\text { cara presentasi }\end{array}$ & $\begin{array}{l}20 \\
\text { menit }\end{array}$ \\
\hline & Kegiatan & Presentas & 70 \\
\hline
\end{tabular}

\begin{tabular}{|l|l|l|l|}
\hline & & & \\
\hline & Kegiatan & $\bullet \quad$ Pengajar & 10 \\
penutup & $\begin{array}{l}\text { memberikan } \\
\text { tanggapan }\end{array}$ & menit \\
& & $\begin{array}{l}\text { terhadap } \\
\text { presentasi } \\
\text { pembelajar }\end{array}$ & \\
\hline
\end{tabular}

\section{Pengumpulan Data}

a) Data observasi

Data observasi diambil selama pelaksanaan pembelajaran kaiwa dasar dengan penerapan project work dengan penulis sebagai observer. Penulis mencatat hal-hal penting yang terjadi pada saat pembelajaran berlangsung.

b) Data lembar kerja

Pembelajar wajib menuliskan lembar kerja yang berisi pertanyaan-pertanyaan interviu dan hasil jawaban teman sejawat yang telah diinterviu. Lembar kerja dikumpulkan setelah 4 kali pembelajaran selesai dilaksanakan.

c) Data angket

Setelah pembelajaran kaiwa usai, penulis meminta pembelajar untuk mengisi angket terbuka terlebih dahulu, kemudian meminta pengisian angket tertutup setelahnya. Angket dituliskan dan dijawab dengan bahasa Indonesia dan tidak ditentukan lamanya waktu pengisian angket.

Data penelitian ini akan dianalisa secara deskriptif kualitatif dengan langkahlangkah sebagai berikut.

a) Memaparkan pelaksanaan pembelajaran kaiwa dengan penerapan project work.

b) Mengidentifikasi kendala-kendala yang muncul selama pelaksanaan pembelajaran

c) Melihat keterlibatan pembelajar melalui lembar kerja yang telah dikumpulkan 
d) Mengelompokkan hasil jawaban angket pembelajar

\section{HASIL DAN PEMBAHASAN}

Dalam perkuliahan Kaiwa yang menerapkan project work, pembelajar diminta untuk membuat poster mengenai satu dari lima tema yang disediakan oleh pengajar. Tema tersebut antara lain, keluarga, percintaan, waktu senggang, perkuliahan dan internet. Pada pertemuan pertama, masingmasing kelompok bebas memilih salah satu tema tersebut. Selanjutnya, pembelajar diminta untuk memikirkan empat buah pertanyaan tentang tema tersebut yang ingin ditanyakan kepada orang lain. Setelah itu, dilaksanakan diskusi di dalam kelompok untuk membahas pertanyaan yang telah dibuat. Masing-masing anggota kelompok mengemukakan pertanyaan yang telah dibuatnya dan memberikan alasan kenapa pentingnya pertanyaan tersebut. Setelah itu, masing-masing kelompok diminta untuk memilih empat pertanyaan terbaik yang diajukan oleh anggota kelompoknya. Pertanyaan itulah yang dijadikan sebagai dasar pelaksanaan interviu.

Setelah pertanyaan interviu tersusun, pada pertemuan kedua, setiap kelompok diminta untuk menginterviu seluruh teman sejawatnya yang berjumlah 44 orang, termasuk anggota kelompok itu sendiri. Kelompok yang hanya terdiri atas 3 atau 4 orang pembelajar harus berdiskusi dan menentukan pembagian kerja interviu. Apabila dilihat dari jumlah teman sejawat dan jumlah anggota kelompok, seorang anggota kelompok memiliki tugas untuk melakukan interviu terhadap 14 sampai dengan 15 orang teman sejawat. Namun, pembagian tugas itu dapat berbeda tergantung dari kesepakatan kelompok.
Setelah seluruh data interviu didapatkan, masing-masing kelompok diharuskan untuk berdiskusi dan menyimpulkan hasil interviu kedalam poster. Poster akan dipresentasikan di kelas pada pertemuan ketiga dan keempat. Presentasi poster dilaksanakan seperti pameran, dimana beberapa grup secara bersamaan melaksanakan presentasi poster, sementara kelompok yang tidak melaksanakan presentasi dapat melihatlihat hasil karya kelompok lain dan memberikan pendapat dan sarannya.

b) Kondisi Pembelajar Selama Penerapan Project Work

Selama empat kali perkuliahan berlangsung, peneliti menuliskan kejadiankejadian yang terjadi dalam catatan penelitian. Kejadian-kejadian tersebut antara lain apa yang peneliti lakukan selama perkuliahan, apa yang pembelajar lakukan selama perkuliahan, serta kejadian-kejadian tak terduga yang terjadi. Dari catatan tersebut proses pembelajaran dengan baik. Walaupun kemampuan bahasa Jepang pembelajar termasuk dalam kemampuan dasar (初級), tapi pembelajar antusias mengerjakan proyek yang diberikan terbukti bahwa semua grup mampu mempresentasikan poster karya mereka.

Apabila dilihat dari rencana pelaksanaan pembelajaran, banyak kegiatan yang lebih terpusat kepada pembelajar. Pada saat diskusi dalam kelompok, terlihat bahwa salah satu anggota kelompok memegang kendali sebagai pemimpin. Pemimpin kelompok ini secara aktif mengemukakan pendapatnya dan menanyakan pendapat anggota kelompok yang lain. Selain itu, pemimpin kelompok dapat menyokong teman-temannya yang pasif dalam diskusi, tidak mampu mengutarakan pendapat 
dikarenakan kemampuan bahasa Jepang yang tidak memadai.Selanjutnya akan dibahas mengenai keterlibatan pembelajar saat pembelajar melaksanakan interviu.

Sebelum pembelajar melaksanakan interviu, pengajar terlebih dahulu mencontohkan bagaimana cara melakukan interviu dalam bahasa Jepang. Pengajar menekankan pada digunakannya salam pembuka untuk memulai interviu, kemudian pengajar menunjukkan bagaimana mengajukan pertanyaan dan terakhir berterima kasih pada orang yang diinterviu karena telah bersedia bekerja sama. Saat itu, sebagian besar pembelajar mencatat apa yang telah dijelaskan. Pada saat melaksanakan interviu, terlihat beberapa orang pembelajar yang melihat-lihat catatan yang ditulis sambil melaksanakan interviu kepada teman sejawat. Namun, karena pembelajar diharuskan menginterviu lebih dari 10 orang, banyak dari mereka yang tidak lagi melihat catatan setelah melakukan interviu kepada beberapa orang teman sejawat. Dapat diambil kesimpulan bahwa dengan banyaknya intensitas penggunaan bahasa Jepang yang sama berulang-ulang, pembelajar secara tidak sadar dapat mengingat cara dan bahasa yang dipergunakan saat menginterviu dalam bahasa Jepang.
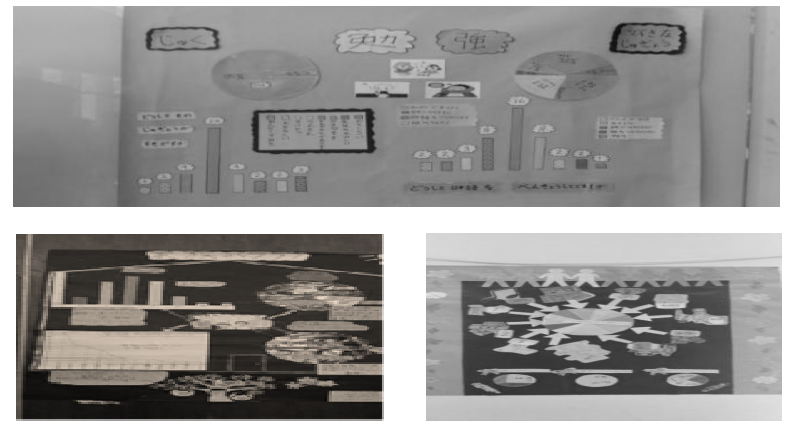

Gambar 1. Hasil Poster Beberapa Grup Mahasiswa c) Permasalahan Saat Penerapan Project Work

Setelah melaksanakan 1 siklus perbaikan pengajaran dengan menerapkan project work pada mata kuliah kaiwa, peneliti melihat ada 3 masalah yang dihadapi saat penerapan project work. Masalah yang pertama adalah saat setiap kelompok mempersiapkan interviu dengan menentukan tema dan pertanyaan yang diajukan. Saat itu, peneliti tidak begitu jelas memaparkan pentingnya dilaksanakan interviu terhadap teman sejawat mengenai tema-tema yang sudah ditetapkan. Sehingga banyak kelompok yang tidak mampu menyiapkan pertanyaan yang saling berhubungan dalam interviu. Sebagai contoh, pada sebuah kelompok yang memilih tema keluarga, menetapkan 4 buah pertanyaan sebagai berikut.

1) Apa yang disukai oleh keluargamu?

2) Bagaimana tanggapan keluargamu terhadap bahasa Jepang?

3) Berapa orang anggota keluargamu?

4) Apakah keluargamu tinggal di Pekanbaru?

Dari keempat pertanyaan tersebut tidak saling berkaitan dan terkesan acak. Pada saat pembelajar menyimpulkan hasil interviu kedalam poster, sulit diambil kesimpulan yang dapat menyatukan keempat pertanyaan tersebut. Dari hal ini dapat ditarik kesimpulan bahwa perlunya apersepsi mengenai tema sebelum project work dilaksanakan. Pembelajar harus dapat merasakan urgensi diadakannya interviu sehingga dapat melaksanakan interviu yang memiliki kesimpulan yang bermakna.

Permasalahan kedua adalah mengenai waktu dan pembagian tugas interviu. Seperti yang telah dipaparkan sebelumnya, pada perkuliahan ini, setiap pembelajar dituntut untuk melaksanakan interviu terhadap 10 
sampai 15 orang. Apabila dilihat dari porsi waktu yang diberikan (lihat tabel 1) selama 80 menit, hal ini sangat membebankan pembelajar. Ditengah proses interviu, banyak dari pembelajar yang terlihat kelelahan dengan tingginya intensitas kegiatan sementara waktu yang disediakan tidak mencukupi. Melihat hal ini, pengajar harus mampu mengukur kemampuan pembelajar dan menyesuaikan waktu perkuliahan. Apabila waktu yang tersedia singkat, maka pengajar perlu mempertimbangkan pembagian kelompok.

Permasalahan terakhir adalah pada saat presentasi poster. Pada saat presentasi poster, pengajar menetapkan kelompok 1 sampai dengan 7 adalah grup penampil pertama yang mempresentasikan posternya, sementara kelompok 8 sampai dengan 14 bertindak sebagai grup penonton yang memberikan pendapat dan masukan pada grup penampil. Pada pertemuan berikutnya, kelompok 8 sampai dengan 14 bertindak sebagai grup penampil, sementara kelompok 1 sampai dengan 7 bertindak sebagai grup penonton. Sebelum melaksanakan presentasi poster, peneliti telah menginstruksikan pada grup penonton untuk memberikan tanggapan dan saran serta mencatat hal-hal menarik tentang presentasi grup penampil. Walaupun demikian, masih banyak pembelajar yang terlihat bosan dan tidak melaksanakan instruksi yang penulis berikan.

Untuk melihat tanggapan pembelajar mengenai penerapan project work pada mata kuliah kaiwa, dilaksanakan pengambilan angket. Angket yang digunakan adalah angket terbuka dan angket tertutup. Angket berfokus menanyakan 3 hal yaitu, kesan terhadap perkuliahan dengan menerapkan project work, hal baik dari penerapan project work, dan kepercayaan pembelajar terhadap keterampilan berbicara dalam bahasa Jepang.

Apabila dilihat dari hasil angket terbuka, sebagian besar pembelajar memberikan kesan yang positif terhadap penerapan project work. Sementara, hasil angket tertutup menunjukkan seperti yang tercantum dalam tabel 3 berikut.

Tabel 3. Kesan Pembelajar Terhadap Penerapan Project Work

\begin{tabular}{|c|c|c|c|c|c|c|}
\hline Pernyataan & $\begin{array}{l}S \\
S\end{array}$ & $S$ & $\begin{array}{l}\mathrm{R} \\
\mathrm{R}\end{array}$ & $\begin{array}{l}T \\
S\end{array}$ & $\begin{array}{l}\text { ST } \\
\text { S }\end{array}$ & $\begin{array}{c}\text { rerat } \\
\mathrm{a}\end{array}$ \\
\hline $\begin{array}{l}\text { Selama } \\
\text { penerapan } \\
\text { project work, } \\
\text { pelajaran } \\
\text { kaiwa terasa } \\
\text { menyenangka } \\
\text { n }\end{array}$ & $\begin{array}{l}1 \\
5\end{array}$ & $\begin{array}{l}2 \\
7\end{array}$ & 1 & 0 & 0 & $\begin{array}{c}4.325 \\
6\end{array}$ \\
\hline $\begin{array}{l}\text { Saya merasa } \\
\text { terpaksa } \\
\text { untuk } \\
\text { mengerjakan } \\
\text { tugas pada } \\
\text { project work }\end{array}$ & 0 & 1 & 2 & $\begin{array}{l}2 \\
2\end{array}$ & 19 & $\begin{array}{c}4.340 \\
9\end{array}$ \\
\hline $\begin{array}{l}\text { Saya merasa } \\
\text { pelaksanaan } \\
\text { kaiwa dengan } \\
\text { penerapan } \\
\text { project work } \\
\text { hanya } \\
\text { membuang- } \\
\text { buang waktu } \\
\text { saja }\end{array}$ & 0 & 0 & 2 & $\begin{array}{l}2 \\
3\end{array}$ & 19 & $\begin{array}{c}1.613 \\
6\end{array}$ \\
\hline $\begin{array}{l}\text { Saat } \\
\text { presentasi } \\
\text { kelompok, } \\
\text { saya tidak } \\
\text { tertarik untuk } \\
\text { melihat }\end{array}$ & 0 & 2 & 9 & $\begin{array}{l}2 \\
4\end{array}$ & 9 & $\begin{array}{c}2.090 \\
9\end{array}$ \\
\hline
\end{tabular}




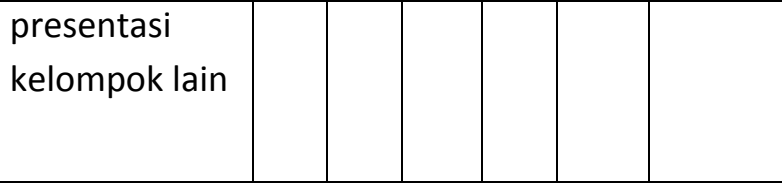

Dari tabel tersebut diketahui bahwa Sebagian besar siswa setuju bahwa penerapan project work terasa menyenangkan dengan rerata 4.33

Selanjutnya pada angket terbuka yang menanyakan mengenai hal apa yang menarik dalam penerapan project work, sebanyak 38.6 $\%$ pembelajar menyebutkan bahwa selama perkuliahan mereka dapat berbicara sambil berlatih percakapan dengan teman sejawat menggunakan bahasa Jepang, 34.4\% menyebutkan bahwa melaksanakan interviu adalah bagian yang menarik, dan $22.7 \%$ menjawab banyak hal menarik yang didapat dari mengerjakan dan mendengar presentasi. Hal ini menunjukkan bahwa pembelajar memiliki keinginan untuk berlatih berbahasa Jepang dengan teman sejawatnya.

\section{SIMPULAN}

Dalam pembelajaran kaiwa, pengajar sering kali menggunakannya sebagai kesempatan bagi pembelajar untuk melatih tata bahasa yang dipelajari di perkuliahan tata bahasa (bunpou) sehingga banyak aktifitas perkuliahan kaiwa berfokus pada latihan pola kalimat atau menghafal contoh percakapanyang terdapat dalam buku teks. Penelitian ini membahas tentang penerapan project work pada mata kuliah kaiwa dengan bertujuan melihat keterlibatan pembelajar dalam pembelajaran dan mencari tahu mengenai pendapat mereka terhadap penerapan project work dalam perkuliahan kaiwa. Dari perkuliahan yang dilaksanakan sebanyak empat kali ditemukan bahwa pembelajar terlibat secara aktif dalam pembelajaran. Terlihat bahwa pembelajar yang memiliki kemampuan komunikasi dan leadership yang lebih baik memberikan sokongan agar pembelajar yang memiliki kemampuan lebih rendah dapat berpartisipasi dalam perkuliahan. Ketaktifan itu juga terlihat dari antusiasnya pembelajar untuk berkomunikasi meskipun mereka memiliki keterbatasan dalam kemampuan bahasa Jepang, dan dapat menyelesaikan proyek kelompoknya. Terhadap penerapan project work ini, sebagian besar pembelajar memberikan tanggapan yang positif dan menyebutkan bahwa dapat berbicara dengan teman menggunakan bahasa Jepang adalah hal yang menarik yang mereka lakukan.

Selain hal-hal positif, dalam penerapan project work kali ini ditemukan beberapa kendala seperti waktu dan pembagian kerja kelompok, kemampuan pembelajar untuk berfikir kritis mengenai proyek yang mereka lakukan dan pelaksanaan presentasi poster. Untuk itu, sebagai masukan dalam pelaksanaan project work, diperlukan apersepsi yang dilakukan oleh pengajar mengenai proyek, sebelum proyek tersebut dikerjakan. Selain itu, perlu adanya manajemen waktu yang lebih baik. Pada presentasi poster, pengajar juga perlu memikirkan cara presentasi poster yang lebih menarik dan interaktif sehingga, pembelajar yang berperan sebagai audiens tidak pasif dan merasa bosan. 
DAFTAR PUSTAKA

Kamada, O \& Kawaguchi, Y. 2007. Nihongo Kyoujuhou Waakushoppu. Tokyo. Bonjinsha

Kono, Toyoko. 2003. Ninzuu no Ooi Nihongo Kaiwa Jugyou de no Kokoromi - Purojekuto Waaku wo Tsuujite. Tokyo. Meikai Japanese Language Journal (8), 61-69

Matsuda. Yuichi. 2002. Kaigai de no Purojekuto Waaku ga Gakushuu Ishiki ni Oyobosu Kouka. Seoul. Kankoku Nihongo Gakkai dai 6 kai Gakujutsu Happyoukai Ronbunshuu .

Noda. Hisashi. 2012. Nihongo Kyouiku no Tame no Komyunikeeshon Kenkyuu. Tokyo. Kuroshio Shuppan

Sanjaya. Wina. 2010. Penelitian Tindakan Kelas. Prenada Media Grup
Sutedi. Dedi. 2009. Penelitian Pendidikan Bahasa Jepang. Bandung. UPI Press dan Humaniora Utama Press

Tarigan. Henry Guntur. 2008. Berbicara: Sebagai Keterampilan Berbahasa. Bandung. Angkasa

The Japan Foundation. 2007. Nihongo Kyoujuuhou Siriizu dai 6 kan Hanasu Koto wo Oshieru. Tokyo: Hitsuji Shobo

2013. Nihongo Kyouiku Kikan Chousa-Kekka Gaiyou-. Tokyo. Kuroshio Shuppan 